\title{
Milk protein genetic variants and isoforms identified in bovine milk representing extremes in coagulation properties
}

\author{
H. B. Jensen, ${ }^{\star 1}$ J. W. Holland, $†$ N. A. Poulsen, ${ }^{\star}$ and L. B. Larsen* \\ *Department of Food Science, Aarhus University, 8830 Tjele, Denmark \\ †Institute for Molecular Bioscience, University of Queensland, QLD 4067, Australia
}

\begin{abstract}
A gel-based proteomic approach consisting of 2-dimensional gel electrophoresis coupled with mass spectrometry was applied for detailed protein characterization of a subset of individual milk samples with extreme rennet coagulation properties. A milk subset with either good or poor coagulation abilities was selected from 892 Danish Holstein-Friesian and Jersey cows. Screening of genetic variants of the major milk proteins resulted in the identification of common genetic variants of $\beta$-casein $\left(\mathrm{CN} ; \mathrm{A}^{1}, \mathrm{~A}^{2}, \mathrm{~B}\right), \kappa-\mathrm{CN}(\mathrm{A}$, $\mathrm{B}$ ), and $\beta$-lactoglobulin (LG; A, B), as well as a low frequency variant, $\kappa-\mathrm{CN}$ variant $\mathrm{E}$, and variants not previously reported in Danish breeds (i.e., $\beta-\mathrm{CN}$ variant I and $\beta$-LG variant $\mathrm{C}$ ). Clear differences in the frequencies of the identified genetic variants were evident between breeds and, to some extent, between coagulation groups within breeds, indicating that an underlying genetic variation of the major milk proteins affects the overall milk coagulation ability. In milk with good coagulation ability, a high prevalence of the $\mathrm{B}$ variants of all 3 analyzed proteins were identified, whereas poorly coagulating milk was associated with the $\beta-\mathrm{CN}$ variant $\mathrm{A}^{2}, \kappa-\mathrm{CN}$ variant $\mathrm{A}$ or $\mathrm{E}$, and $\beta$-LG variant $\mathrm{A}$ or $\mathrm{C}$. The $\beta-\mathrm{CN}$ variant I was identified in milk with both good and poor coagulation ability, a variant that has not usually been discriminated from $\beta-\mathrm{CN}$ variant $\mathrm{A}^{2}$ in other studied cow populations. Additionally, a detailed characterization of $\mathrm{k}$-CN isoforms was conducted. Six $\kappa-\mathrm{CN}$ isoforms varying in phosphorylation and glycosylation levels from each of the genetic variants of $\kappa$-CN were separated and identified, along with an unmodified $\kappa$-CN form at low abundance. Relative quantification showed that around $95 \%$ of total $\kappa-\mathrm{CN}$ was phosphorylated with 1 or 2 phosphates attached, whereas approximately $35 \%$ of the identified $\kappa$-CN was glycosylated with 1 to 3 tetrasaccharides. Comparing
\end{abstract}

Received January 13, 2012.

Accepted February 2, 2012.

${ }^{1}$ Corresponding author: hanne.bakjensen@agrsci.dk isoforms from individual samples, we found a very consistent $\kappa-\mathrm{CN}$ isoform pattern, with only minor differences in relation to breed, $\kappa$-CN genetic variant, and milk coagulation ability.

Key words: rennet coagulation, milk protein genetic variant, posttranslational modification, mass spectrometry

\section{INTRODUCTION}

In Denmark, cheese production has steadily increased during the past decade, rising to $320.9 \mathrm{t} / \mathrm{yr}$ in 2009, when it was estimated that $47 \%$ of bovine milk production was used for cheese making (Danish Dairy Board, 2010). Rennet coagulation of milk is essential because it is the foundation of the cheese-making process and affects both cheese yield and quality; hence, it is of great importance for the dairy industry.

The initial phase of rennet coagulation, also called renneting, is the chymosin-catalyzed cleavage of $\kappa$-CN between the residues $\mathrm{Phe}^{105}$ and $\mathrm{Met}^{106}$, resulting in a hydrolytic split into an insoluble para- $\kappa-\mathrm{CN}(\kappa-\mathrm{CN}$ peptide 1-105) and a soluble hydrophilic caseinomacropeptide ( $\kappa-\mathrm{CN}$ peptide 106-169) released to the whey, subsequently leading to micellar destabilization (Sandra et al., 2007). The second phase of coagulation is nonenzymatic. When approximately $85 \%$ of the $\kappa-\mathrm{CN}$ is hydrolyzed, the destabilized casein micelles start a spontaneous aggregation, resulting in a gel-like network; that is, the curd or coagulum (Green and Morant, 1981; Fox and McSweeney, 1998). Great variability in rennet coagulation in milk between individual cows has been observed in several studies and various breeds, and poorly coagulating or noncoagulating milk is a common problem (Ikonen et al., 1999, 2004; Tyriseva et al., 2004; Wedholm et al., 2006; Joudu et al., 2007). In a study of Danish Red, Holstein-Friesian, and Jersey cows, more than $20 \%$ of milk samples were found to be poorly coagulating, and of these $3 \%$ were completely noncoagulating (Frederiksen et al., 2011b). Multiple genetic and environmental factors affect milk coagulation, including health status and lactation stage of the cow (Auldist et al., 1996), breed (Auldist et al., 
2002; Wedholm et al., 2006), season (O'Brien et al., 1999), feeding (Verdier-Metz et al., 1998), and genetic polymorphism in the milk proteins and composite genotypes (Ekstrand et al., 1981; Hallén et al., 2007).

In the present study, we investigated the association between genetic variants and isoforms of major milk proteins and milk coagulation traits. Genetic variants of the caseins and major whey proteins contribute significantly to the variation in rennet coagulation properties, where the most consistent results found are that the $\mathrm{B}$ variants of $\beta-\mathrm{CN}, \kappa-\mathrm{CN}$, and $\beta-\mathrm{LG}$ are favorable for milk coagulation and cheese-making (Ikonen et al., 1997, 1999; Di Stasio and Mariani, 2000; Wedholm et al., 2006; Hallén et al., 2007, 2008). Several genetic variants of these 3 milk proteins have been identified, where amino acid changes in the mature milk protein are the result of polymorphisms in the corresponding gene. Lien et al. (1999) studied common genetic variants in Danish Holstein-Friesian and Jersey cows; $\beta-\mathrm{CN}$ (allele frequencies of variants; $\mathrm{A}^{2}>\mathrm{A}^{1}>\mathrm{B}>\mathrm{A}^{3}$ ), $\kappa-\mathrm{CN}(\mathrm{A}>\mathrm{B}>\mathrm{E}$ ), and $\beta-\mathrm{LG}$ (Holstein-Friesian: A $>\mathrm{B}$; Jersey: $\mathrm{B}>\mathrm{A}$ ); allele frequencies that resemble those found in other studies (Summer et al., 1996; Hallén et al., 2007; 2008; Heck et al., 2009).

In addition to variation of genetic variants, bovine $\kappa-\mathrm{CN}$ is present as multiple isoforms due to differential posttranslational modifications (PTM) varying in phosphorylation (from 1 to 3 phosphates attached; potential sites: $\mathrm{Ser}^{148}$, $\mathrm{Thr}^{166}$, $\mathrm{Ser}^{170}$ ) and glycosylation [from 1 to 6 glycans attached; potential sites: $\mathrm{Thr}^{142}$, $\mathrm{Thr}^{152}$, $\mathrm{Thr}^{154}$, $\mathrm{Thr}^{157}$ (A variant only), $\mathrm{Thr}^{163}$, and $\left.\mathrm{Thr}^{186}\right]$, where sites vary from being either constitutively or partially modified (Pisano et al., 1994; Holland et al., 2006). It has been hypothesized that variations in glycosylation of $\kappa$-CN could influence coagulation properties of milk (Tyriseva et al., 2008). Glycosylation of $\kappa-\mathrm{CN}$ is predominantly in the form of $O$-linked glycans, where the major glycan is a tetrasaccharide composed of galactose (Gal), $\mathrm{N}$-acetylgalactosamine (GalNAc), and sialic or neuraminic acid (NeuAc) in the form NeuAc $\alpha(2-3) \operatorname{Gal} \beta(1-3)[\operatorname{NeuAc} \alpha(2-6)]$ GalNAc. Also, monosaccharides (structure: GalNAc), disaccharides $[\mathrm{Gal} \beta(1-3) \mathrm{GalNAc}]$, and trisaccharides $\{\operatorname{NeuAc\alpha }(2-3)$ Gal $\beta(1-3)$ GalNAc or Gal $\beta(1-3)[\operatorname{NeuAc\alpha }(2-6)]$ GalNAc $\}$ have been found (van Halbeek et al., 1980; Fiat et al., 1988; Saito and Itoh, 1992). Robitaille et al. (1991a,b) measured the NeuAc content of $\kappa-\mathrm{CN}$ and found great variability in their measurements (555 individual samples; mean $64 \pm 21 \mu \mathrm{g} / \mathrm{mg}$; range, $23-166 \mu \mathrm{g} / \mathrm{mg}$ ). However, a recent study performed on a limited number of 2-dimensional electrophoresis gels suggested the pattern of glycosylation to be far more consistent than the above-mentioned measurements would indicate
(Holland et al., 2004, 2005). Studies comparing к-CN isoforms in individual milk samples are few, thus, mass spectrometry-based proteomics could be promising to examine potential association of PTM with coagulation properties of bovine milk.

The present investigation was carried out as part of the Danish-Swedish Milk Genomic Initiative and comprised detailed proteomic characterization of milk samples that represented extremes in rennet coagulation properties. The objective of the present study was to use 2-dimensional gel electrophoresis (2-DE) coupled with MS analysis for protein profiling of individual milk samples from 2 Danish dairy breeds, Holstein-Friesian and Jersey. The aim was identification of genetic variants of major milk proteins of importance for coagulation; that is, $\beta-\mathrm{CN}, \kappa-\mathrm{CN}$, and $\beta-\mathrm{LG}$, as well as analysis of $\kappa$-CN isoform distribution in relation to PTM, focusing on relative quantification of the phospho- and glyco- forms in relation to milk coagulation properties.

\section{MATERIALS AND METHODS}

\section{Animals and Collection of Milk Samples}

Morning milk was obtained from 892 individual Danish cows (456 Holstein-Friesians and 436 Jerseys) collected from October 2009 to April 2010 from herds in Jutland, Denmark. The cows were selected from 42 herds based on pedigree for maximum number of sires represented. All cows were in mid lactation, housed in loose housing systems, fed according to standard practice, and milked twice a day. Immediately after milking, milk samples were placed on ice for transport to the laboratory. Once at the laboratory, the milk samples were aliquoted, skimmed (centrifuged for $30 \mathrm{~min}$ at $2,643 \times g$ at $4^{\circ} \mathrm{C}$ ), and refrigerated at $5^{\circ} \mathrm{C}$ for up to $6 \mathrm{~h}$ without preservatives before being subjected to rheological analysis. Each milk sample was analyzed for somatic cell count using Fossomatic 5000 (Foss Electric, Eurofins Laboratory, Holstebro, Denmark), and samples with an $\mathrm{SCC}>500 \times 10^{3}$ cells $/ \mathrm{mL}$ were excluded from further study.

\section{Dynamic Rheological Analysis}

Dynamic rheological analyses were carried out in duplicate by measuring rennet (chymosin)-induced milk coagulation using a ReoRox4 rheometer (MediRox AB, Nyköping, Sweden) on skim milk, essentially as described earlier (Frederiksen et al., 2011b). Rennet coagulation time (RCT), maximum coagulum strength by storage modulus $\mathrm{G}^{\prime}\left(\mathbf{G}_{\text {max }}^{\prime}\right)$, and curd firming rate (CFR) were selected to describe the coagulation prop- 
erties of the individual milk samples. The RCT was defined as the time where the phase angle $\theta=45^{\circ}$; $\mathrm{G}_{\text {max }}^{\prime}$ was equal to the maximum value of the storage modulus $\mathrm{G}^{\prime}$ obtained within $1 \mathrm{~h}$ of measurement; and CFR $\left[\Delta \mathrm{G}^{\prime} / \Delta \mathrm{t}\right]_{\text {lin }}$ was calculated from consecutive points of the linear part of the gelation profile.

\section{Milk Sample Subset}

A milk sample subset, consisting of 24 samples from each of the 2 Danish breeds, Holstein-Friesian or Jersey, was selected from the collected samples based exclusively on the rheological analysis data. In the subset, a combination of values for RCT and CFR defined 2 coagulation groups containing milk samples with either good or poor coagulating ability (12 samples per coagulating group for each breed). The $\mathrm{G}_{\text {max }}^{\prime}$ was monitored but not included in the selection criteria for coagulation grouping because of technical difficulties in the measurements of samples with high values, especially as observed for the Jersey milk samples (Frederiksen et al., 2011b). The subsets thus represented the most extreme samples with regard to rennet coagulation from the large screening. Mean and standard error on the measured coagulation properties were calculated for each coagulation group.

\section{2-DE}

In addition to the 48 individual samples, pooled milk samples from each of the 2 coagulation groups (good and poor) from each breed were analyzed using 2-DE, essentially as described by Holland et al. (2004). The pooled milk samples with good and poor coagulating ability were furthermore subjected to affinity $\kappa-\mathrm{CN}$ enrichment using biotinylation and avidin capture of protein as described by Holland et al. (2006) and subsequently subjected to 2-DE analysis.

In short, whole milk samples were solubilized 1:45 ( $\mathrm{vol} / \mathrm{vol})$ in $8 \mathrm{M}$ urea containing $4 \% 3[(3$-cholamidopropyl)dimethylammonio]-propanesulfonate (CHAPS), and incorporated into 24-cm $\mathrm{pH}$ 4-7 immobilized $\mathrm{pH}$ gradient (IPG) strips (Amersham Biosciences, Uppsala, Sweden) using passive rehydration loading. Strips were focused in an IPGphor isoelectric focusing unit (Amersham Biosciences) at $100 \mathrm{~V}$ for $1 \mathrm{~h}$ followed by 500 $\mathrm{V}$ for $1 \mathrm{~h}$ and $1 \mathrm{kV}$ for $1 \mathrm{~h}$ before the voltage was increased to $8 \mathrm{kV}$ for a total of $100 \mathrm{kVh}$. Sodium dodecyl sulfate-PAGE was performed on $14 \%$ gels $(25.5$ $\times 20 \mathrm{~cm})$ in an Ettan Dalt Six electrophoresis unit (Amersham Biosciences) at $5 \mathrm{~mA} /$ gel for $2 \mathrm{~h}$ followed by $20 \mathrm{~mA} /$ gel for $16 \mathrm{~h}$. Gels were stained with colloidal Coomassie Blue G-250 and destained in 1\% acetic acid.
Gel images were captured using an ImageScanner (Amersham Biosciences).

\section{In-Gel Tryptic Digests}

Gel plugs of 1 to $2 \mathrm{~mm}$ in diameter were excised from selected protein spots, washed in water for $30 \mathrm{~min}$, and destained with two 30-min washes in $40 \mathrm{mM}$ ammonium bicarbonate/50\% acetonitrile (ACN). The gel pieces were dehydrated with $100 \%$ ACN for 10 min and rehydrated with $20 \mu \mathrm{L}$ of a freshly prepared solution of a modified porcine trypsin solution $(10 \mu \mathrm{g} / \mathrm{mL}$ in 40 $\mathrm{m} M$ ammonium bicarbonate, $\mathrm{pH}$ 8; Sigma, St. Louis, $\mathrm{MO})$ and incubated at $37^{\circ} \mathrm{C}$ overnight. The trypsin solution was removed and gel pieces were suspended in $20 \mu \mathrm{L}$ of $5 \%$ formic acid in $50 \% \mathrm{ACN}$ and sonicated for $5 \mathrm{~min}$. The extraction was repeated and extracts were combined with the trypsin solution and dried in a vacuum centrifuge.

\section{Matrix-Assisted Laser Desorption/lonization-Time- of-Flight MS Analysis}

Tryptic peptide extracts were mixed with an equal volume of sinapinic acid matrix $(20 \mathrm{mg} / \mathrm{mL})$ in $1 \%$ formic acid $/ 50 \%$ ACN and spotted onto a stainless-steel matrix-assisted laser desorption/ionization (MALDI) target, followed by peptide mass fingerprinting (PMF) analysis in positive ion linear mode using a Voyager-DE STR MALDI-time-of-flight MS (Applied Biosystems, Foster City, CA). Spectra were obtained with an accelerating voltage of $25 \mathrm{kV}$, grid voltage at $93 \%$, and a delay time of $975 \mathrm{~ns}$, and each spectrum comprised 500 laser shots (100 shots at 5 distinct target positions). Spectra were processed by default baseline correction and resolution-based smoothing using Data Explorer Software (version 4.9, Applied Biosystems) and calibrated internally using known peaks for $\beta$-CN (peak $m / z 2,187,3,723), \kappa-\mathrm{CN}(m / z 1,252,1,981,4,012)$, and $\beta$-LG $(m / z 1,194,1,636,2,709)$.

\section{Quantitative Image Analysis}

Gel spots were detected and quantified using PDQuest 2-D analysis software (version 8.0, Bio-Rad, Hercules, CA). The spots were quantified by adding the pixel intensities within the spot boundary, corresponding to the amount of protein in the spot, and the spot volumes were calculated. Annotated $\kappa$-CN spots were manually edited in all 48 individual samples, where relative spot volumes were calculated for each separate gel to overcome gel-to-gel variations in spot intensities and sample loadings. The amount of samples with 
a homozygote $\kappa-\mathrm{CN}$ variant was reduced by $50 \%$ to enable comparison with heterozygote samples. Means and standard errors of spot volumes were calculated for spots identified as $\kappa$-CN variants and isoforms.

\section{RESULTS}

\section{Milk Sample Subset}

Rheological data for the subset of 48 milk samples analyzed from Danish Holstein-Friesian and Jersey cows representing either good or poor coagulation ability are shown in Table 1 . The milk samples with good coagulating properties were characterized by having a low RCT and high $\mathrm{G}_{\text {max }}$ and $\mathrm{CFR}$, whereas the samples defined as poorly coagulating had a high RCT, but low $\mathrm{G}_{\text {max }}^{\prime}$ and CFR. Of the 12 poorly coagulating HolsteinFriesian samples, 6 were completely noncoagulating; that is, not able to form a gel within $1 \mathrm{~h}$ after addition of chymosin. In agreement with a previous study conducted by Frederiksen et al. (2011b), milk from Jersey cows generally exhibited superior coagulation properties compared with that from Holstein-Friesian cows, as reflected in a higher $\mathrm{G}^{\prime}{ }_{\max }$ and CFR of Jersey milk in both groups compared with values for HolsteinFriesians.

\section{2-DE of Pooled Milk Samples}

Initially, 2-DE fingerprints were obtained of pooled milk samples from each of the 2 coagulation groups from each breed (Figure 1). Visual inspection of the gels showed 3 areas (marked with boxes in Figure 1) that differed in both presence and relative spot volumes in pooled milk samples with either good or poor coagulation ability from both breeds. The marked proteins were identified as mature $\beta$-CN, multiple isoforms of mature $\kappa-\mathrm{CN}$ that varied in level of phosphorylation and glycosylation, and mature $\beta-\mathrm{LG}$, in agreement with earlier studies (Holland et al., 2004, 2006). The PTM of $\kappa$-CN resulted in a distinct horizontal train of spots as the acidic phosphates or NeuAc residues produced small shifts in the isoelectric point (pI) that allowed distinct resolution of the isoforms by this method. In addition, polymorphisms modifying the AA sequence of the coded protein may produce pI shifts, and the pooled samples should thus represent all possible variants present in the sample subsets.

\section{2-DE of Individual Milk Samples}

The 48 individual samples were successfully analyzed using $2-\mathrm{DE}$ and MS to identify $\beta-\mathrm{CN}, \kappa-\mathrm{CN}$, and $\beta-\mathrm{LG}$ genetic variants.

$\boldsymbol{\beta}-\boldsymbol{C N}$ Genetic Variants. $\beta$-Casein was separated as a horizontal train of 3 dominant spots with a pI range of 4.9 to 5.1 and a mass of approximately $24 \mathrm{kDa}$ in individual samples using 2-DE. Four genetic variants of $\beta$-CN were identified using $\mathrm{MS}\left(\mathrm{A}^{1}, \mathrm{~A}^{2}, \mathrm{~B}, \mathrm{I}\right)$ that constituted 10 genotypes $\left(\mathrm{A}^{1} \mathrm{~A}^{1}, \mathrm{~A}^{2} \mathrm{~A}^{2}, \mathrm{~A}^{1} \mathrm{~A}^{2}, \mathrm{BB}, \mathrm{A}^{1} \mathrm{~B}\right.$, $\mathrm{A}^{2} \mathrm{~B}, \mathrm{IB}, \mathrm{II}, \mathrm{A}^{1} \mathrm{I}, \mathrm{A}^{2} \mathrm{I}$; Figure $2 \mathrm{~A}$ ). Table 2 summarizes the AA substitutions of the $\beta-\mathrm{CN}$ variants compared with the $\mathrm{A}^{2}$ reference protein: $\mathrm{A}^{1}$ variant $\left(\mathrm{Pro}^{82} \rightarrow \mathrm{His}\right.$ ), $B$ variant $\left(\operatorname{Pro}^{82} \rightarrow\right.$ His and $\left.\operatorname{Ser}^{137} \rightarrow \mathrm{Arg}\right)$, I variant $\left(\mathrm{Met}^{93} \rightarrow\right.$ Leu). Analysis by 2 -DE could separate most of the $\beta-\mathrm{CN}$ variants into separate gel spots by utilizing their different mobility on gels (acidity; $\mathrm{A}^{2}=\mathrm{I}>\mathrm{A}^{1}>$ $\mathrm{B})$, with the exception of the $\mathrm{A}^{2}$ and I variants located at the same gel position. Using MS analysis, however, it was possible to discriminate all $4 \beta$-CN variants. Spectra showing PMF analysis of in-gel tryptic digests of the $4 \beta-\mathrm{CN}$ variants (spots 1-4) are compared in Figures $2 \mathrm{~B}$ and $2 \mathrm{C}$. The $\beta$-CN variants could be identified using specific tryptic peptides (Table 2 ): $\beta-\mathrm{CN} \mathrm{A}^{2}$ (peptides; $m / z 5,320$ and 6,363), $\beta$-CN A ${ }^{1}(m / z 5,360$ and 6,363$), \beta-\mathrm{CN} \mathrm{B}(m / z 1,138,5,313$, and 6,432$)$, and $\beta-\mathrm{CN} \mathrm{I}(\mathrm{m} / z 5,302$ and 6,363$)$.

$\kappa-C N$ Genetic Variants. Analysis of $\kappa-\mathrm{CN}$ by 2-DE gave a rather complex gel picture due to considerable microheterogeneity in $\kappa-\mathrm{CN}$ arising from the presence of genetic variants and PTM. Figure 3A shows the 2-DE profile of $3 \mathrm{MS}$-identified $\kappa$-CN genetic vari-

Table 1. Dynamic rheological data (mean \pm SE) of milk sample subsets representing extremes in rennet coagulation ability (good or poor) selected as extreme coagulators from 892 individual milk samples from Holstein-Friesian and Jersey cows $(\mathrm{n}=48)$

\begin{tabular}{|c|c|c|c|c|c|}
\hline Breed & $\begin{array}{l}\text { Coagulation } \\
\text { ability }\end{array}$ & Number & \multicolumn{3}{|c|}{ Rheometry $^{1}$} \\
\hline Holstein-Friesian & Poor & 12 & $21.3 \pm 1.31$ & $38.88 \pm 14.14$ & $1.35 \pm 0.44$ \\
\hline \multirow[t]{2}{*}{ Jersey } & Good & 12 & $12.42 \pm 0.10$ & $800.22 \pm 26.01$ & $34.27 \pm 0.39$ \\
\hline & Poor & 12 & $25.46 \pm 0.69$ & $272.05 \pm 9.87$ & $9.00 \pm 0.25$ \\
\hline
\end{tabular}

${ }^{1} \mathrm{RCT}=$ rennet coagulation time; $\mathrm{G}^{\prime} \max =$ coagulum strength; CFR $=$ curd firming rate. 

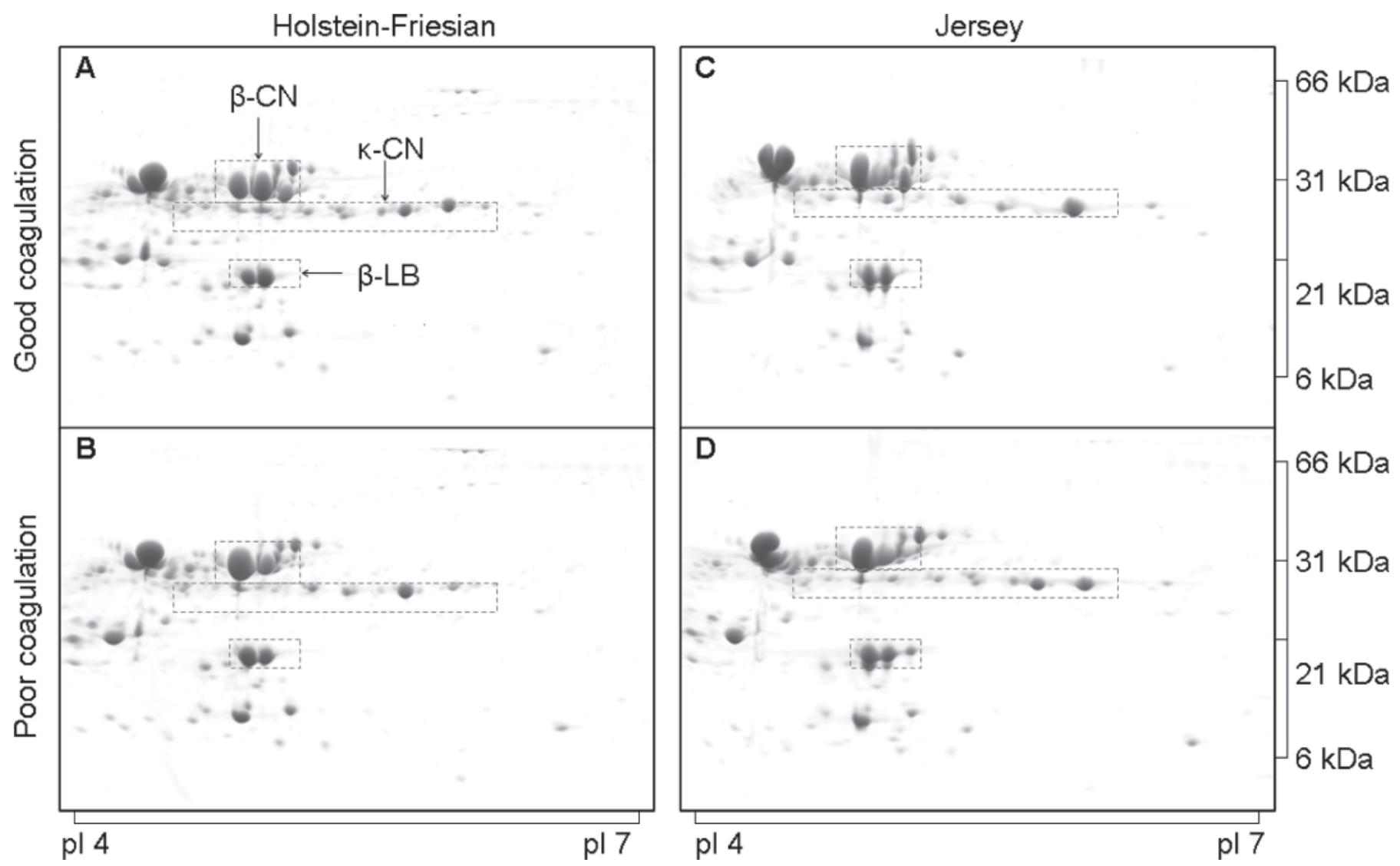

Figure 1. 2-Dimensional gel electrophoresis comparison of milk samples with either good or poor coagulation ability. Pooled milk samples ( $\mathrm{n}=12$ samples/breed/coagulation ability) were focused using $\mathrm{pH} 4-7$ immobilized $\mathrm{pH}$ gradient strips and electrophoresed using $14 \%$ polyacrylamide gels. Gels were stained with colloidal Coomassie Blue G-250. Three boxes in each gel mark protein spots identified as $\beta$-CN, $\kappa-\mathrm{CN}$, or $\beta$-LG.

ants $(\mathrm{A}, \mathrm{B}, \mathrm{E})$ in the $\mathrm{pI}$ range of 4.5 to 6.3 found in individual milk samples, which constituted 4 genotype combinations (AA, BB, AB, AE). Isoelectric separation could distinguish between the $\mathrm{B}$ variant in relation to the $\mathrm{A}$ and $\mathrm{E}$ variants, whereas the $\mathrm{A}$ and $\mathrm{E}$ variants were located in the same gel position, as explained by the AA substitutions of these variants (Table 2). Compared with the reference $\kappa-C N$ variant $\mathrm{A}$, the $\mathrm{B}$ variants contained $2 \mathrm{AA}$ substitutions $\left(\mathrm{Asp}^{169} \rightarrow\right.$ Ala and $\mathrm{Thr}^{174} \rightarrow$ Ile), whereas the $\mathrm{E}$ variant contained 1 AA substitution (Ser ${ }^{176} \rightarrow$ Gly), thus giving variability in acidity (variant $\mathrm{A}=\mathrm{E}>\mathrm{B}$ ). However, using MS analysis, it was possible to distinguish variant $\mathrm{A}$ from both variants B and E. Spectra showing PMF of in-gel tryptic digests of the most abundant $\mathrm{k}-\mathrm{CN}$ isoform of the $3 \mathrm{\kappa}$-CN variants (the form with 1 phosphate group attached; spots 5-7) are compared in Figures $3 \mathrm{~B}$ and $3 \mathrm{C}$, showing specific tryptic peaks for the variants; variant $\mathrm{A}(\mathrm{m} / z 5,536,6,022$, and 6,150$)$, variant $\mathrm{B}(\mathrm{m} / \mathrm{z}$ $5,504,5,990$, and 6,118), and variants $\mathrm{A}$ and $\mathrm{E}$ located in the same spot (yielding the peaks $m / z 5,506 / 5,536$, $5,992 / 6,022$, and 6,120/6,150, respectively).

$\boldsymbol{\beta}-\boldsymbol{L} \boldsymbol{G}$ Genetic Variants. For $\beta-\mathrm{LG}, 3$ variants (A, B, C) were separated as a train of 3 horizontal spots positioned on the 2-DE gels in the pI range 4.9 to 5.1, with a mass of approximately $19 \mathrm{kDa}$ constituting 5 genotypes identified using $\mathrm{MS}$ in individual samples (AA, BB, AB, AC, BC; Figure 4A). Compared with the reference protein ( $\beta-\mathrm{LG}$ variant $\mathrm{B})$, the $\mathrm{A}$ variant contained 2 AA substitutions $\left(\mathrm{Gly}^{80} \rightarrow\right.$ Asp and Ala ${ }^{134}$ $\rightarrow \mathrm{Val}$ ), whereas only $1 \mathrm{AA}$ change was present in the $\mathrm{C}$ variant $\left(\mathrm{Gln}^{75} \rightarrow\right.$ His; Table 2$)$, thus changing the acidity and thereby the 2-DE gel mobility of the variants (acidity: variant $\mathrm{A}>\mathrm{B}>\mathrm{C}$ ). Spectra showing $\mathrm{PMF}$ of in-gel tryptic digests of the $3 \beta$-LG variants (spots 8-10) are compared in Figures $4 \mathrm{~B}$ and $4 \mathrm{C}$. Specific tryptic peptides for the A variant $(m / z 2,314,2,848$, and 3,475$)$, the B variant $(m / z 2,314,2,820$, and 3,417$)$, and $\mathrm{C}$ variant $(m / z 2,323,2,820$, and 3,426$)$ were used to identify the protein variants. 
A
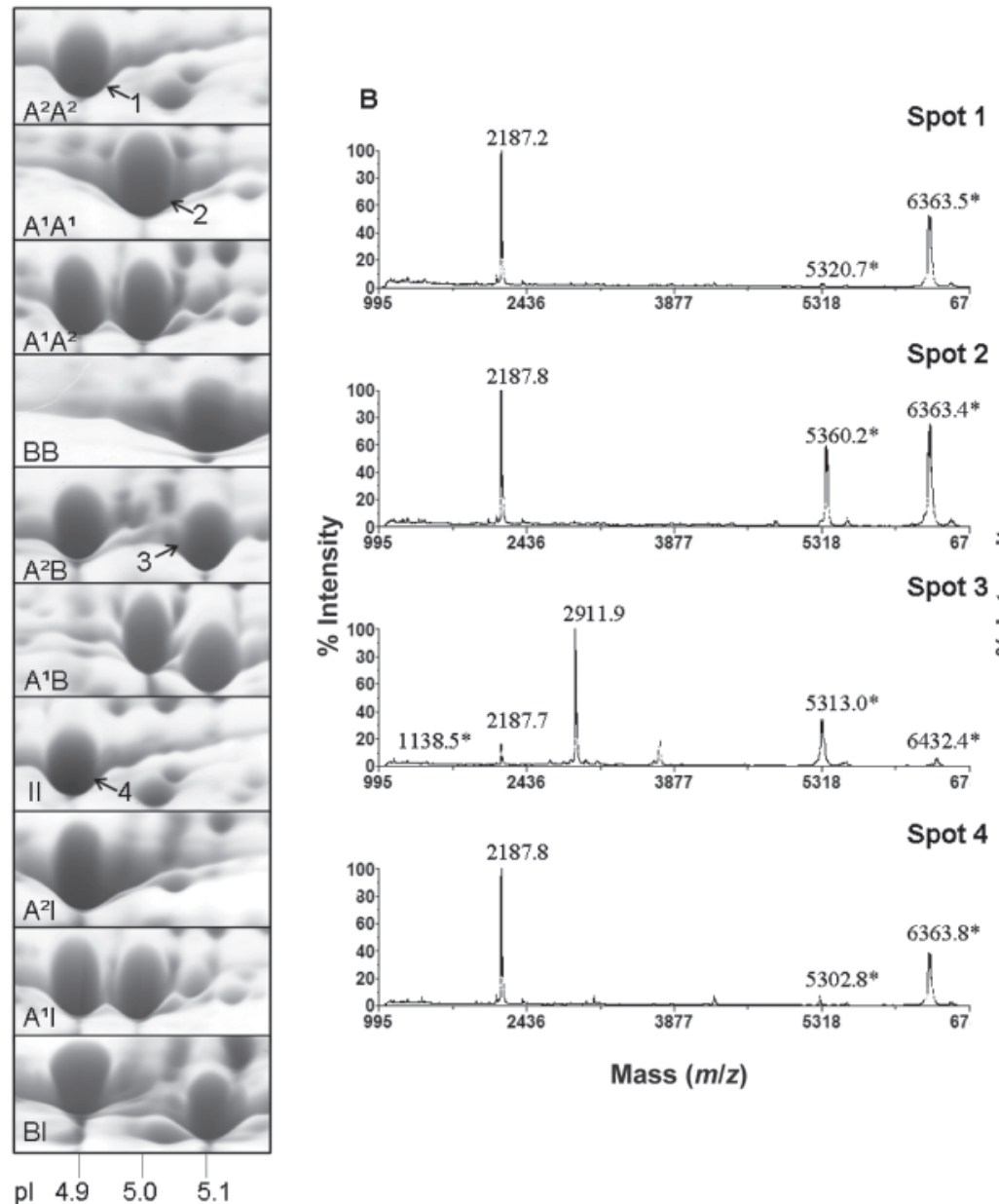

C

Spot 1
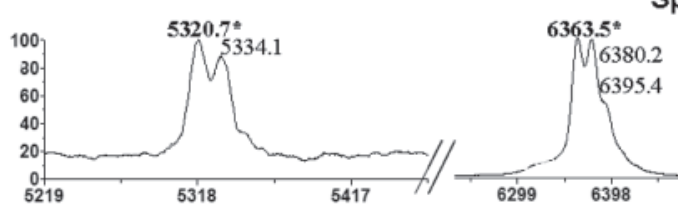
(3).2
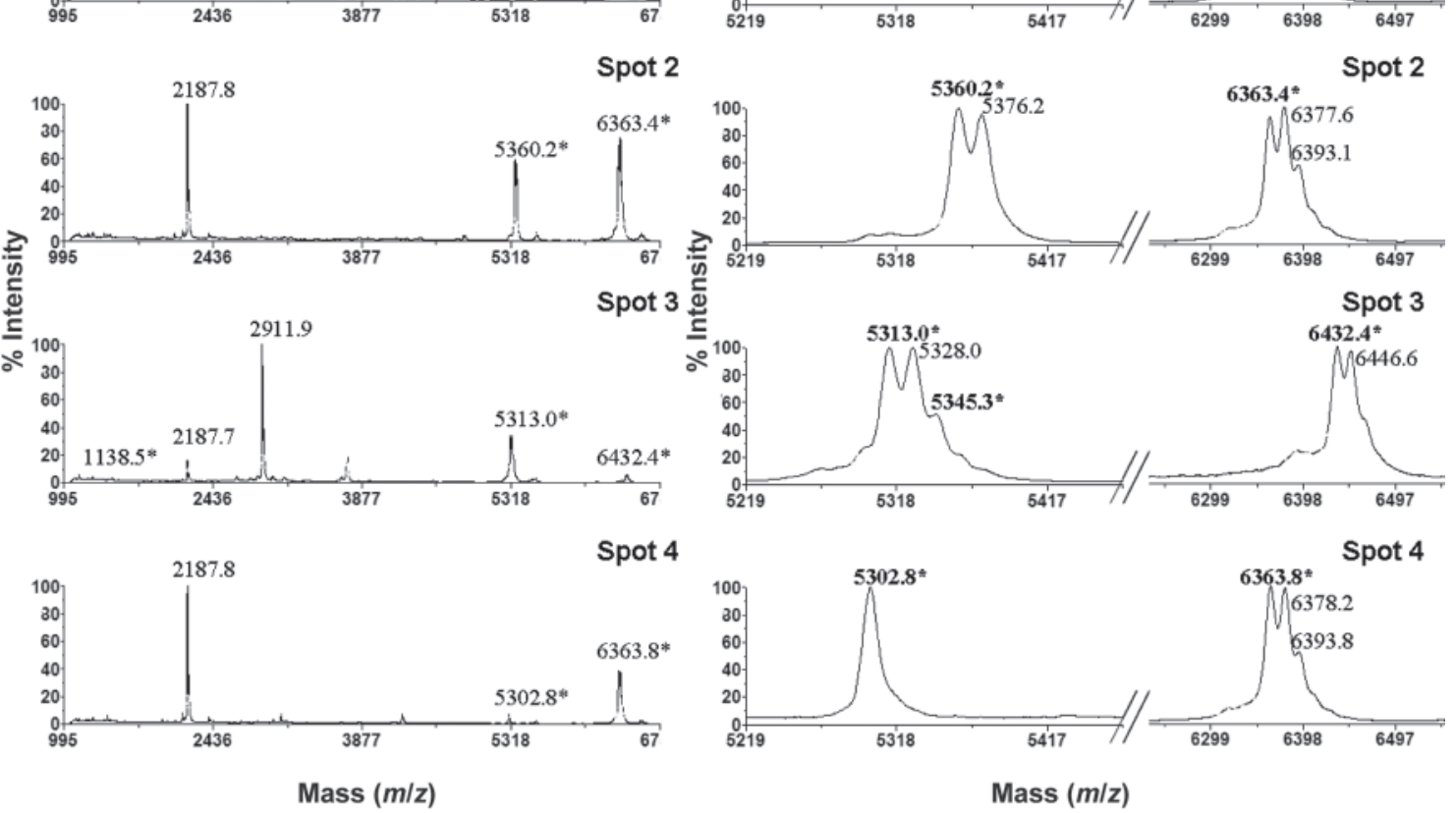

Figure 2. $\beta$-Casein genetic variants. (A) Region of 2-dimensional electrophoresis (2-DE) gel showing $\beta$-CN variants $\left(A^{2}, A^{1}, B, I\right)$ and genotypes $\left(\mathrm{A}^{2} \mathrm{~A}^{2}, \mathrm{~A}^{1} \mathrm{~A}^{1}, \mathrm{~A}^{1} \mathrm{~A}^{2}, \mathrm{BB}, \mathrm{A}^{2} \mathrm{~B}, \mathrm{~A}^{1} \mathrm{~B}, \mathrm{BI}, \mathrm{II}, \mathrm{A}^{2} \mathrm{I}, \mathrm{A}^{1} \mathrm{I}\right)$ identified in individual milk samples. The 2-DE analysis could not distinguish between the $\mathrm{A}^{2}$ and I variants. (B) Mass spectra analyzing tryptic digest of spots 1 to 4 marked in (A). (C) Zoom of panel (B) showing specific peaks (marked with $*$ ) identifying the $\beta$-CN variants: spot $1=$ variant $\mathrm{A}^{2}$ (peak with $m / z 5,320$ and 6,363 ); spot $2=\operatorname{variant~} \mathrm{A}^{1}(\mathrm{~m} / z 5,360$ and 6,363 ); spot $3=$ variant $\mathrm{B}(\mathrm{m} / z 1,138,5,313$, and 6,432$)$; spot $4=$ variant $\mathrm{I}(\mathrm{m} / z 5,302$ and 6,363$)$.

\section{Summary of Genotype Profiling}

Table 3 summarizes the genotype distributions of $\beta-\mathrm{CN}, \kappa-\mathrm{CN}$, and $\beta$-LG identified in the milk subsets for both breeds. Even though a relatively small number of animals were included in this study, genotype differences between the breeds and, to some extent, between coagulation groups within the breeds were obvious. In both breeds, $\beta-\mathrm{CN}$ variant $\mathrm{B}$ was only identified in good coagulating milk, and this coagulation group also had a high frequency of $\kappa-\mathrm{CN}$ variant $\mathrm{B}$, as either $\mathrm{BB}$ or $\mathrm{AB}$ genotypes. $\beta$-Casein variant $\mathrm{I}$ was identified in several milk samples with both good and poor coagulating ability in both breeds. Poorly coagulating milk, however, was dominated by the $\beta-\mathrm{CN}$ variant $\mathrm{A}^{2}$ variant and $\kappa-\mathrm{CN}$ variant $\mathrm{A}$. Only in Holstein-Friesian milk, $\kappa-\mathrm{CN}$ variant $\mathrm{E}$ was identified in poorly coagulating milk, whereas in Jersey milk, only $\beta$-LG variant C was identified in 2 poorly coagulating milk samples. In both coagulation groups, the majority of the samples were genotyped $\beta-\mathrm{LG} \mathrm{AB}$, although a higher frequency of $\beta-L G$ variant $B$ was found in milk with good coagulating ability.

\section{k-CN Isoform Separation and Relative Quantification}

As the resolution of $\kappa-\mathrm{CN}$ isoforms on 2-DE gels can be restricted by abundant $\alpha_{\mathrm{S}^{-}}$and $\beta-\mathrm{CN}$ that migrate to similar regions as the more acidic $\kappa-\mathrm{CN}$ isoforms (see Figure 1), an enrichment procedure for $\kappa$-CN coupled to 2-DE and MS identification was performed 
Table 2. Summary of specific peptides used to identify genetic variants of $\beta-\mathrm{CN}, \kappa-\mathrm{CN}$, and $\beta-\mathrm{LG}^{1}$

\begin{tabular}{|c|c|c|c|c|c|}
\hline Protein & \multicolumn{4}{|c|}{ Variant $^{2}$} & Residues \\
\hline \multirow[t]{4}{*}{$\beta-\mathrm{CN}$} & - & $\mathrm{Pro}^{82} \rightarrow$ His & $\begin{aligned} \operatorname{Pro}^{82} & \rightarrow \text { His } \\
\operatorname{Ser}^{137} & \rightarrow \text { Arg }\end{aligned}$ & Met $^{108} \rightarrow$ Leu & \\
\hline & $5,320.2$ & $5,360.2$ & $5,360.2$ & $5,302.2$ & $64-112$ \\
\hline & $6,363.3$ & $6,363.3$ & $6,432.4^{3}$ & $6,363.3$ & 129-184 \\
\hline & & & $5,313.2^{*}$ & & $138-184$ \\
\hline \multirow[t]{4}{*}{$\kappa-\mathrm{CN}$} & - & $\mathrm{Thr}^{157} \rightarrow$ Ile & $\operatorname{Ser}^{176} \rightarrow$ Gly & & \\
\hline & $5,536.9$ & $5,504.9$ & $5,506.9$ & & $138-190$ \\
\hline & $6,022.4$ & $5,990.0$ & $5,992.4$ & & $134-190$ \\
\hline & $6,150.6$ & $6,118.6$ & $6,120.6$ & & $133-190$ \\
\hline & $3,417.8$ & $3,475.8$ & $3,426.8$ & & $57-85$ \\
\hline
\end{tabular}

${ }^{1}$ In-gel tryptic digest from gel spots were analyzed with matrix-assisted laser desorption/ionization time-of-flight (MALDI-TOF) MS in positive linear mode using sinapinic acid matrix.

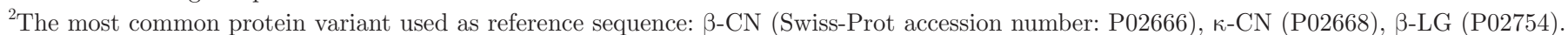
The AA substitutions in the protein variants are noted according to previous studies (Caroli et al., 2009), and the sequences are numbered starting from the signal peptide. Masses of specific peptides are given as average masses (Da) as $[\mathrm{M}+\mathrm{H}]^{+}$. The masses noted are without modifications.

${ }^{3}$ This AA substitution introduces a tryptic cleavage site $(\mathrm{Arg})$ into the sequence, which results in 2 peptides $\left(\right.$ marked ${ }^{*}$ and $\left.*^{*}\right)$.

on pooled Holstein-Friesian milk $(\mathrm{n}=24)$. Figure 5A shows the 2-DE gel of such an enriched $\kappa-\mathrm{CN}$ sample, where the marked spots corresponded to 6 identified $\kappa-\mathrm{CN}$ isoforms for each genetic variant as described previously (Holland et al., 2006). Again, the A and E variants had the same location on the gel. The isoforms were positioned on the gel as a horizontal train of spots, as the acidic phosphate or NeuAc glycans produced small shifts in the pI that allowed resolution of the isoforms. The most abundant isoforms on the gels were identified; forms varying in phosphorylation ( 1 or 2 phosphates attached) and glycosylation (from 1 to 3 glycans attached). Also, weaker spots of unmodified $\kappa$-CN variants were identified (not visible in Figure $5 \mathrm{~A}$ ), along with spots tailing the train of the identified isoforms, most likely being more modified $\kappa$ - $\mathrm{CN}$ forms, but MS identification was not possible due to their low abundance.

The structural predictions based on mobility on the 2 -DE gel allowed us to assign the correct $\mathrm{k}$-CN isoforms in all 2-DE gels when analyzing the individual milk samples from which relative quantitative analysis was performed. Figure 5B and $\mathrm{C}$ show the relative amounts of $\kappa$ - $\mathrm{CN}$ isoforms relative to total $\kappa-\mathrm{CN}$ on each gel in terms of genetic variants (A, B and $\mathrm{A}$ or $\mathrm{E})$, number of phosphates (1P and $2 \mathrm{P}$ ) and tetrasaccharides (1G, $2 \mathrm{G}$, and $3 \mathrm{G}$ ) attached. It was not possible to assign the level to the E variant alone, as no EE homozygotes were included in the study, and $\kappa-\mathrm{CN} \mathrm{A}$ and $\mathrm{E}$ variants had the same position in the gels. The results show a remarkably consistent PTM distribution between individual samples in both breeds, where $\mathrm{k}-\mathrm{CN}$ isoform abundance was found to be in the order of $\kappa-\mathrm{CN} 1 \mathrm{P}>$ $2 \mathrm{P}>1 \mathrm{P}+1 \mathrm{G}>1 \mathrm{P}+2 \mathrm{G}>1 \mathrm{P}+3 \mathrm{G}>$ unmodified. Clearly, the $\kappa-\mathrm{CN}$ form with 1 phosphate and no glycans attached was the most abundant isoform, comprising approximately 45 to $50 \%$ of total $\kappa$-CN. Our analysis also showed that the majority of the $\mathrm{k}$ - $\mathrm{CN}$ molecules were phosphorylated $(95-96 \%$ of total $\kappa-\mathrm{CN})$, whereas a much lower amount of glycosylation with up to 3 tetrasaccharide glycans was observed (34-36\% of total $\kappa-\mathrm{CN})$. In addition, the unmodified isoform without any PTM accounted for only 4 to $5 \%$ of total $\kappa-\mathrm{CN}$ in both breeds, with the exception of $\kappa-\mathrm{CN}$ variant $\mathrm{A}$ in Holstein-Friesian cows, which reached $11 \%$ of total $\kappa-\mathrm{CN}$. Otherwise, the $\kappa-\mathrm{CN}$ variants in both breeds showed a consistent isoform pattern among individual cows and across genetic $\kappa-\mathrm{CN}$ variants. Finally, the samples were examined according to coagulation ability and no significant variability in $\kappa-\mathrm{CN}$ PTM distribution 
between samples having either good or poor coagulation was observed (data not shown), again suggesting a very consistent pattern of isoform distribution.

\section{DISCUSSION}

The applied proteomic gel-based approach allowed identification of multiple genetic variants of $\beta-\mathrm{CN}$, $\kappa-\mathrm{CN}$ and $\beta-\mathrm{LG}$, along with $6 \kappa-\mathrm{CN}$ isoforms, in 48 individual milk samples with either extremely good or extremely poor coagulation ability.

In the present study, several commonly found $\beta-\mathrm{CN}$ variants $\left(\mathrm{A}^{1}, \mathrm{~A}^{2}\right.$, and $\left.\mathrm{B}\right)$ were identified. In addition, the $\beta-\mathrm{CN}$ variant I was identified in both coagulation groups, which to our knowledge have not been identified previously in these 2 Danish dairy breeds. Studies reporting the $\beta-\mathrm{CN}$ variant I are few, yet allele frequency reports of 0.13 for $\beta-C N$ variant I in Dutch Holstein-Friesian cows (Visker et al., 2011) and of 0.12 in Italian Holstein-Friesian cows (Jann et al., 2002) indicate that it might be a relatively common variant. The $\beta$-CN variant I may not have been noticed in previously studied populations, because the analytical techniques used to determine protein variants were not suited for discrimination of variant I from variant $\mathrm{A}^{2}$. The $\beta$-CN variants $\mathrm{I}$ and $\mathrm{A}^{2}$ have the same $\mathrm{pI}$ value and, in the present study, variants I and $\mathrm{A}^{2}$ could not be discriminated electrophoretically, but required MS analysis for identification. Furthermore, the $\beta-\mathrm{CN}$ variant $\mathrm{B}$ was identified only in samples with good coagulating ability in both breeds. This is in line with earlier observations that superior milk coagulation characteristics were linked to $\beta$-CN variant B (Di Stasio and Mariani, 2000; Hallén et al., 2007, 2008). The majority of poorly coagulating samples were genotyped $\mathrm{A}^{2} \mathrm{~A}^{2}$, in agreement with coagulation results from Swedish Red and Holstein, where a higher RCT and lower G'max were observed for $\beta-\mathrm{CN} \mathrm{A}^{2} \mathrm{~A}^{2}$ (Hallén et al., 2007).

As $\kappa-\mathrm{CN}$ is an essential protein in renneting and cheese-manufacturing, great focus has been on the effects of $\kappa$-CN on the rheological properties of milk. In accordance with genotype trends in the 2 coagulation groups in the present study, differences in rennet coagulation properties have also been observed for genetic variants of $\kappa-\mathrm{CN}$ in other studies. Thus, shorter RCT, higher G'max, and higher CFR have been reported for milk from cows with the $\kappa$-CN BB genotype than for cows with the AA genotype (Ikonen et al., 1997, 1999; Wedholm et al., 2006; Hallén et al., 2007, 2008). Differences in micelle stability that occur between the $2 \kappa-\mathrm{CN}$ genetic variants, $\mathrm{A}$ and $\mathrm{B}$, have been related to the micelle size and to the glycosylation degree of $\kappa-\mathrm{CN}$ (Di Stasio and Mariani, 2000). In addition, the size of the $\mathrm{CN}$ micelles is inversely related to $\kappa-\mathrm{CN}$
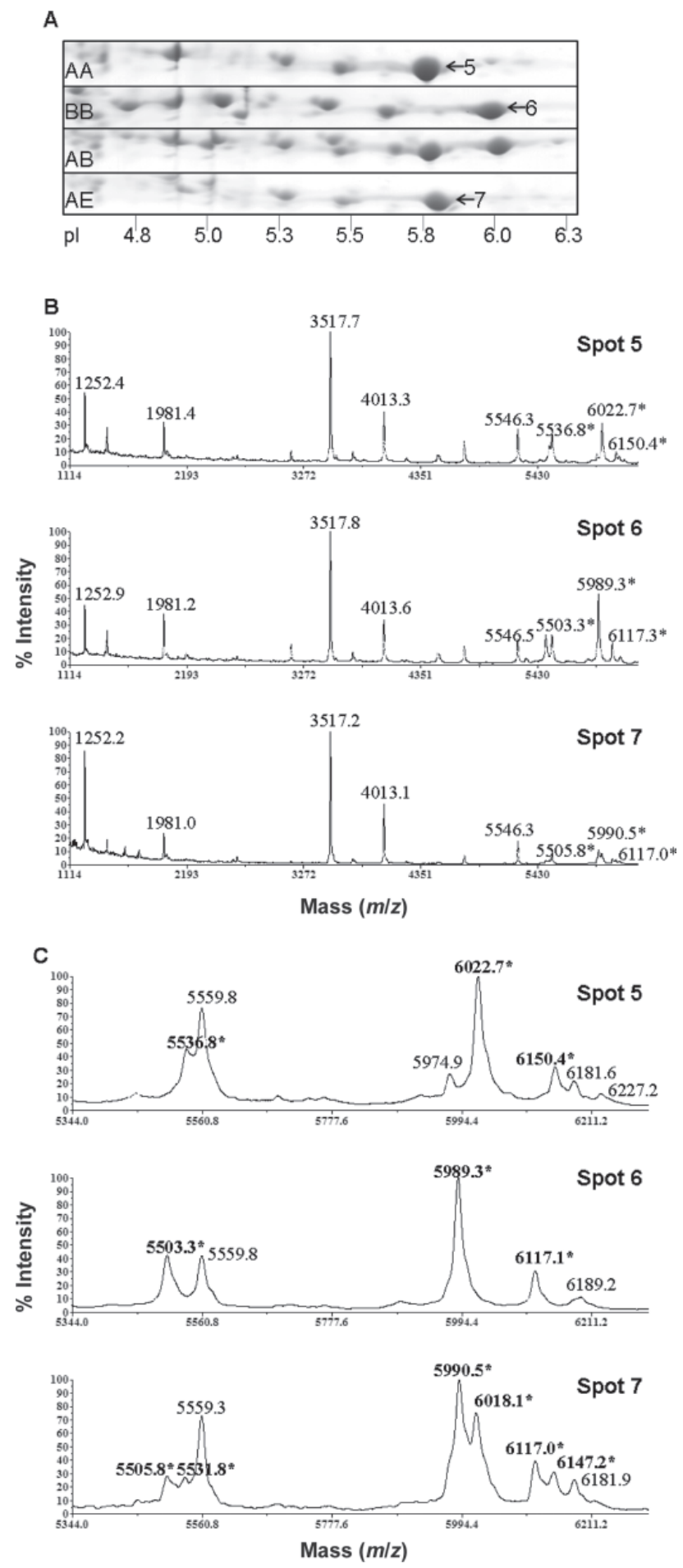

Figure 3. $\kappa$-Casein genetic variants. (A) Region of 2-dimensional electrophoresis (2-DE) gel showing $\kappa$-CN variants (A, B, E) and genotypes (AA, BB, AB, AE) identified in individual milk samples; 2-DE analysis could not distinguish between the A and E variants. (B) Mass spectra analyzing tryptic digest of spots 5 to 7 marked in (A). (C) Zoom of panel (B) showing specific peaks (marked with *) identifying the $\kappa$-CN variants: spot $5=$ variant $\mathrm{A}(\mathrm{m} / z 5,536,6,022$, and 6,150$)$; spot $6=$ variant $\mathrm{B}(\mathrm{m} / z 5,504,5,990$, and 6,118$)$; spot $7=$ variant $\mathrm{A}$ $(\mathrm{m} / z 5,536,6,022$, and 6,150$)$ and variant $\mathrm{E}(\mathrm{m} / z 5,506,5,992$, and $6,120)$. 
A

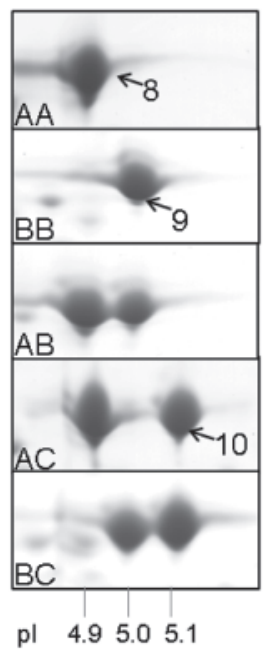

\section{B}
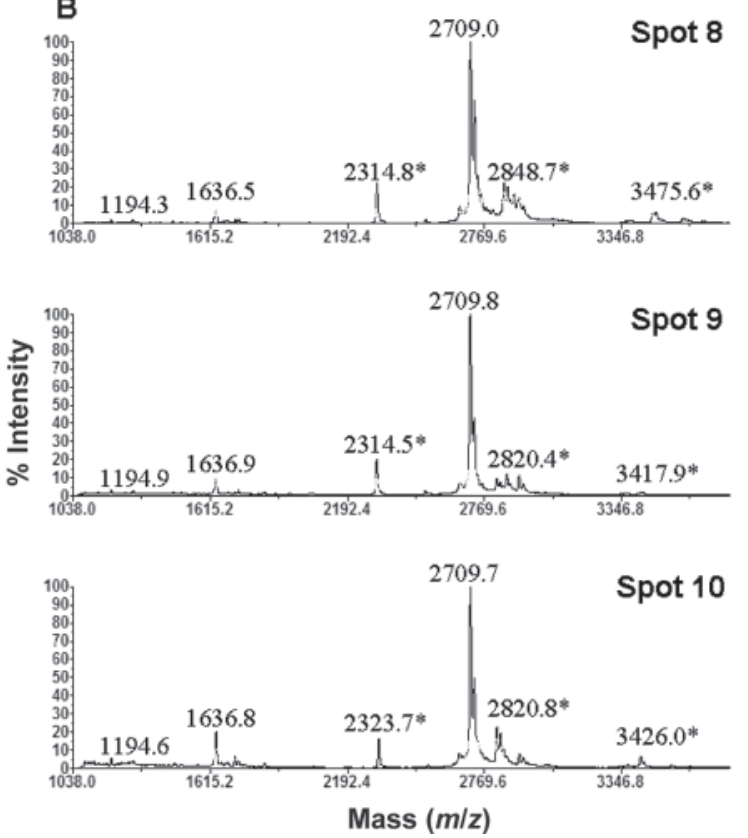

C $2848.7^{*}$
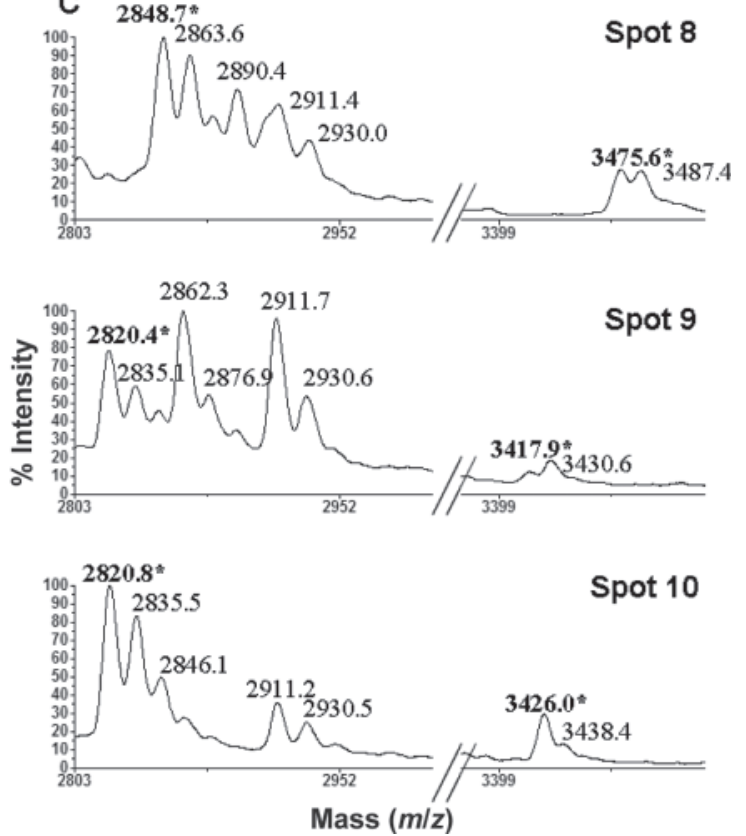

Figure 4. $\beta$-Lactoglobulin variants. (A) Region of 2 -dimensional electrophoresis (2-DE) gel showing $\beta$-LG variants (A, B, C) and genotypes (AA, BB, AB, AC, BC) identified in individual milk samples. (B) Mass spectra analyzing tryptic digest of spots 8 to 10 marked in (A). (C) Zoom of panel (B) showing specific peaks (marked with ${ }^{*}$ ) that identifies the $\beta$-LG variants: spot $8=\operatorname{variant} \mathrm{A}(\mathrm{m} / z 2,848$ and 3,475$)$; spot 9 $=$ variant $\mathrm{B}(m / z 2,820$ and 3,417$) ;$ spot $10=$ variant $\mathrm{C}(\mathrm{m} / z 2,820$ and 3,426$)$.

content (Dalgleish, 1986; O'Connell and Fox, 2000) and coagulation properties, with a clear relationship between larger micelles and poor coagulation properties (Frederiksen et al., 2011a). Furthermore, in 2 poorly coagulating Holstein-Friesian samples, $\kappa$-CN variant $\mathrm{E}$ was identified. A high prevalence of the $\kappa-\mathrm{CN}$ E allele has formerly been reported in some Nordic dairy breeds (Hallén et al., 2007, 2008) and, in agreement with our

Table 3. Distribution of $\kappa-\mathrm{CN}, \beta-\mathrm{CN}$, and $\beta-\mathrm{LG}$ genotypes in Holstein-Friesian and Jersey milk with either extremely good or extremely poor coagulation ability

\begin{tabular}{|c|c|c|c|c|c|}
\hline \multirow{2}{*}{\multicolumn{2}{|c|}{ Protein/genotype $^{1}$}} & \multicolumn{2}{|c|}{ Holstein-Friesian } & \multicolumn{2}{|c|}{ Jersey } \\
\hline & & $\begin{array}{c}\text { Good } \\
(\mathrm{n}=12)\end{array}$ & $\begin{array}{c}\text { Poor } \\
(\mathrm{n}=12)\end{array}$ & $\begin{array}{c}\text { Good } \\
(\mathrm{n}=12)\end{array}$ & $\begin{array}{c}\text { Poor } \\
(\mathrm{n}=12)\end{array}$ \\
\hline \multirow[t]{10}{*}{$\beta-\mathrm{CN}$} & $\mathrm{A}^{1} \mathrm{~A}^{1}$ & 3 & - & - & - \\
\hline & $\mathrm{A}^{2} \mathrm{~A}^{2}$ & - & 8 & 5 & 8 \\
\hline & $\mathrm{A}^{1} \mathrm{~A}^{2}$ & 2 & 3 & - & - \\
\hline & $\mathrm{BB}$ & - & - & 1 & - \\
\hline & $\mathrm{A}^{1} \mathrm{~B}$ & 1 & - & 1 & - \\
\hline & $\mathrm{A}^{2} \mathrm{~B}$ & 3 & - & 2 & - \\
\hline & II & 1 & - & - & - \\
\hline & $\mathrm{A}^{1} \mathrm{I}$ & 2 & - & - & 1 \\
\hline & $\mathrm{A}^{2} \mathrm{I}$ & - & 1 & 2 & 3 \\
\hline & BI & - & - & 1 & - \\
\hline \multirow[t]{4}{*}{$\kappa-\mathrm{CN}$} & $\mathrm{AA}$ & 2 & 9 & - & 4 \\
\hline & $\mathrm{BB}$ & 2 & - & 12 & 4 \\
\hline & $\mathrm{AB}$ & 8 & 1 & - & 4 \\
\hline & $\mathrm{AE}$ & - & 2 & - & - \\
\hline \multirow[t]{5}{*}{$\beta-\mathrm{LG}$} & $\mathrm{AA}$ & - & 1 & 2 & 2 \\
\hline & $\mathrm{BB}$ & 5 & - & 5 & 1 \\
\hline & $\mathrm{AB}$ & 7 & 11 & 5 & 7 \\
\hline & $\mathrm{AC}$ & - & - & - & 1 \\
\hline & $\mathrm{BC}$ & - & - & - & 1 \\
\hline
\end{tabular}

${ }^{1}$ The genotypes were determined using the location of protein spots on 2-dimensional gels coupled with MS analysis. 


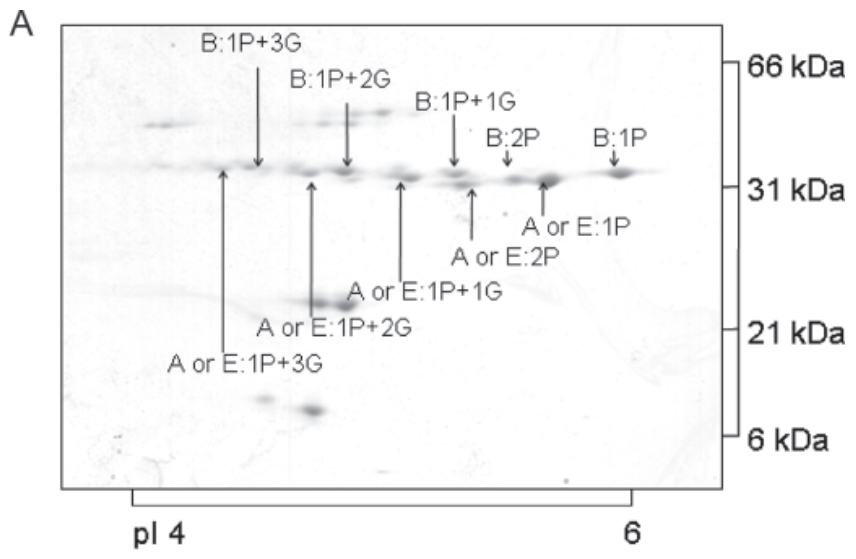

B

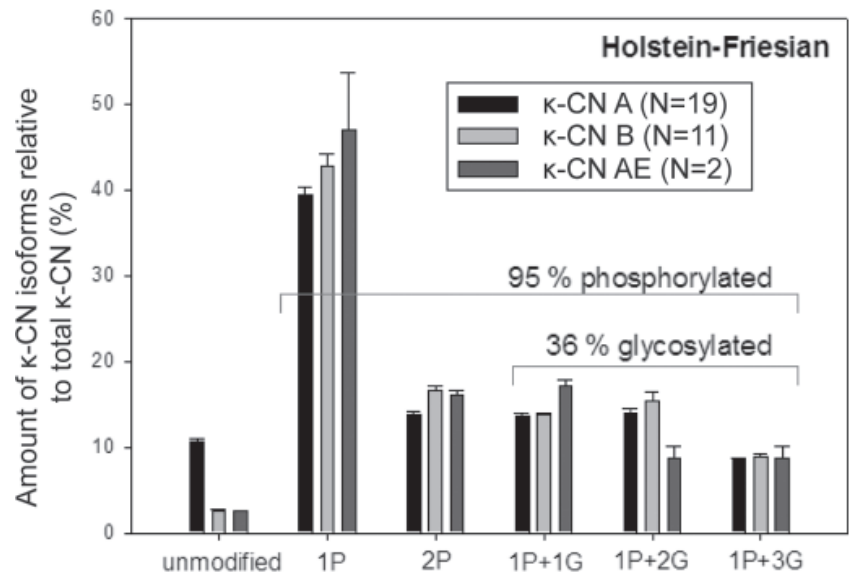

C

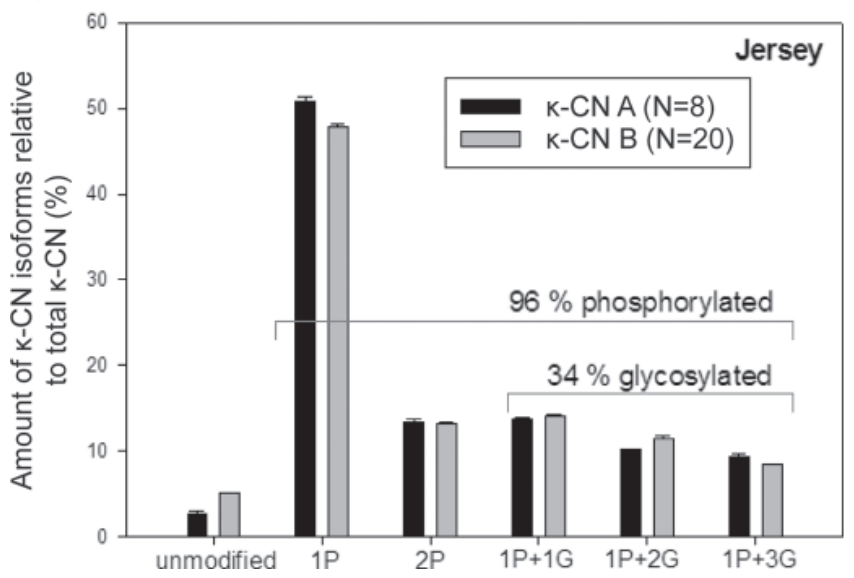

Figure 5. Gel-based separation and relative quantification of $\kappa-\mathrm{CN}$ isoforms. (A) 2-Dimensional electrophoresis (2-DE) gel of enriched $\kappa-\mathrm{CN}$ fraction from pooled Holstein-Friesian milk $(\mathrm{n}=24)$. Spots are labeled with $\kappa-\mathrm{CN}$ variants $(\mathrm{A}, \mathrm{B}, \mathrm{E})$ and with isoform status varying in the number of phosphates $(1 \mathrm{P}, 2 \mathrm{P})$ and tetrasaccharide glycans present (1G, 2G, and 3G; presumed structure: NeuAc $\alpha(2-3) \mathrm{Gal} \beta(1-3)$ $[\operatorname{NeuAc\alpha }(2-6)]$ GalNAc, where NeuAc $=$ neuraminic acid and Gal $=$ galactose). Analysis by 2-DE could not distinguish between the A and $\mathrm{E}$ variants. Panels $(\mathrm{B})$ and $(\mathrm{C})$ show mean relative $\kappa-\mathrm{CN}$ isoform amount relative to total $\kappa$-CN. Quantification was performed using spot volumes from 2-DE gels analyzing individual samples from Holstein-Friesian and Jersey cows. k-Casein variants (A, B, E), number of each $\kappa-\mathrm{CN}$ variant quantified (n), and standard errors are shown. results, an indicated negative association between milk coagulation properties and the E variant has been suggested (Oloffs et al., 1992; Ikonen et al., 1997, 1999; Caroli et al., 2000).

Genetic variants of $\beta$-LG have been shown to have an indirect effect on cheese yield through the level of casein to total protein. The $\beta-\mathrm{LG}$ variant $\mathrm{B}$ is associated with greater cheese yield than the A allele (Schaar et al., 1985; Marziali and Ng-Kwai-Hang 1986; Wedholm et al., 2006), which is probably due to the positive correlation between casein number and $\beta-\mathrm{LG}$ variant B (Schaar et al., 1985; Lundén et al., 1997). In the present study, the majority of samples were genotyped to $\beta$-LG AB in both coagulation groups in both breeds, although milk with good-coagulation ability had a higher prevalence of $\beta$-LG BB, as expected. In addition, $\beta-\mathrm{LG}$ variant $\mathrm{C}$ was identified in 2 poorly coagulating milk samples from Jersey cows with genotypes $\mathrm{AC}$ and $\mathrm{BC}$. The $\mathrm{C}$ variant has not, to our knowledge, been identified before in Danish Jersey cows but has been reported to be relatively common in Jersey cows in general (Caroli et al., 2009).

Even though a relatively small number of samples was analyzed in this study, clear differences in the frequencies of the identified genetic variants were evident between breeds and, to some extent, between coagulation groups within breeds, indicating that the underlying genetic variation of major milk proteins affects the overall milk coagulation ability. In a larger data set than presented in this study, composite $\mathrm{CN}$ genotypes could also be considered because of the tight genetic linkage among the CN genes (Caroli et al., 2009). Recently, Heck et al. (2009) concluded that selection for CSN2-CSN3 $(\beta-\kappa-\mathrm{CN})$ haplotype $\mathrm{A}^{2}-\mathrm{B}$, together with $L G B^{*} B$ ( $\beta$-LG variant $\left.\mathrm{B}\right)$, would result in milk more suitable for cheese-making in Dutch Holstein-Friesians. Partly in accordance with this, the genotyping results obtained in this study suggest that selection for milk with good coagulation ability should favor the B variants of $\beta-\mathrm{CN}, \kappa-\mathrm{CN}$, and $\beta-\mathrm{LG}$ in the investigated Danish breeds.

Little is known about the functional roles of $\kappa$-CN phosphorylation and glycosylation. From a theoretical perspective, a higher initial level of $\kappa$-CN glycosylation is thought to stabilize the micelle structure (Holland, 2009). k-Casein is believed to act as a "hairy" layer on the micelle surface that provides steric and electrostatic repulsion between micelles, preventing aggregation. Glycosylation of $\kappa-\mathrm{CN}$ would increase both the size of the hydrophilic $\kappa$-CN C-terminal and its charge, because of the hydrophilic sugar residues and their hydration shells (Holland, 2009). A possible effect of casein phosphorylation level on the stability against aggregation has been observed (Feagan et al., 1972; 
Frederiksen et al., 2011a). This indicates that the more charged or glycosylated the $\kappa-\mathrm{CN}$, the more stable the casein micelles would be in the second phase of the rennet coagulation.

In accordance with other gel-based studies conducted by Holland et al. (2004, 2005), remarkably similar distribution of $\kappa-\mathrm{CN}$ PTM in 48 individual milk samples was found. For both breeds, the $\kappa_{-} \mathrm{CN}$ isoform abundance was found in the order of $\kappa-\mathrm{CN} 1 \mathrm{P}>2 \mathrm{P}>$ $1 \mathrm{P}+1 \mathrm{G}>1 \mathrm{P}+2 \mathrm{G}>1 \mathrm{P}+3 \mathrm{G}>$ unmodified. In both breeds, the majority of $\kappa-\mathrm{CN}$ was phosphorylated $(94-95 \%$ of total $\kappa-\mathrm{CN})$ and the $\kappa-\mathrm{CN}$ isoform with only 1 phosphate group attached accounted for 45 to $50 \%$ of the total $\kappa-\mathrm{CN}$, whereas, somewhat surprisingly, the identified glycosylated $\kappa$-CN isoforms with up to 3 tetrasaccharides accounted for no more than 34 to $36 \%$ of the total $\kappa-\mathrm{CN}$. At first glance, this is in contrast to Vreeman et al. (1986), who estimated up to $60 \%$ к-CN glycosylation. However, the present study does not give an estimate on total $\kappa$-CN glycosylation, merely on the major glycosylated $\kappa$-CN isoforms with up to 3 glycans attached (there are 6 possible glycan attachments sites; Pisano et al., 1994). In addition, this study did not identify the mono-, di-, or trisaccharides also known to be present at lower levels (Saito and Itoh, 1992), although these $\kappa-\mathrm{CN}$ forms were slightly visible on the gels as faint gel spots following the horizontal train of identified $\kappa$-CN isoforms (Figure 5); due to their low abundance, MS identification was not possible. The $\kappa-\mathrm{CN}$ isoform pattern observed for $\kappa-\mathrm{CN}$ variant $\mathrm{A}$ in Holstein-Friesian cows showed a slightly higher amount of unmodified $\kappa-\mathrm{CN}$ than the other variants. Variation in the distribution of $\kappa-\mathrm{CN}$ PTM have previously been described, where the $\mathrm{B}$ variant of $\kappa$ - $\mathrm{CN}$ has been reported to be more glycosylated than the $\mathrm{A}$ and $\mathrm{E}$ variants (Vreeman et al., 1986; Robitaille et al., 1991a; Mollé and Léonil, 1995; Coolbear et al., 1996), despite the fact that the A variant contains an extra (potential) glycosylation site. $\kappa$-Casein variant $\mathrm{E}$ was identified in 2 heterozygous samples, but it was not possible to discriminate from variant A using isoelectric separation, as these variants have the same pI value. Therefore, the relative quantification of $\kappa-\mathrm{CN}$ AE could mask any possible variation in PTM pattern for the $\mathrm{E}$ variant in relation to the A variant. This could be clarified by quantification of homozygous k-CN EE samples. Finally, the chosen gel-based quantification methods showed a very consistent PTM pattern of $\kappa-\mathrm{CN}$, independent of breed, genetic variant, and coagulation group, indicating that PTM of $\kappa-\mathrm{CN}$ appear to take place in a highly controlled manner and that the process has considerable functional significance. Further investigation using high-resolution proteomic techniques may hold the key to advancing our knowledge of $\kappa-\mathrm{CN}$ PTM and their functional importance, and further enlighten the roles of $\kappa$-CN glycosylation in relation to both phases of rennet-induced coagulation.

\section{CONCLUSIONS}

The proteomic gel-based approach used during this study was suitable for separation and identification of genetic variants of $\beta-\mathrm{CN}, \kappa-\mathrm{CN}$, and $\beta-\mathrm{LG}$ in bovine milk representing rennet coagulation extremes of samples selected from 892 Danish Holstein-Friesian and Jersey cows. Common genetic variants of 3 major milk proteins; that is, $\beta-\mathrm{CN}\left(\mathrm{A}^{1}, \mathrm{~A}^{2}, \mathrm{~B}\right),{ }^{-}-\mathrm{CN}(\mathrm{A}, \mathrm{B})$, and $\beta$-LG $(\mathrm{A}, \mathrm{B})$, were identified, in addition to a rare variant, $\kappa-\mathrm{CN}$ variant $\mathrm{E}$, and variants that have not previously been reported in Danish breeds ( $\beta-\mathrm{CN}$ variant I and $\beta$-LG variant $\mathrm{C}$ ). The genotype trends in our subset indicated a high prevalence of the $\mathrm{B}$ variants of all 3 analyzed proteins in milk with good coagulation ability, whereas poorly coagulating milk was associated with $\beta-\mathrm{CN}$ variant $\mathrm{A}^{2}, \kappa-\mathrm{CN}$ variant $\mathrm{A}$ or $\mathrm{E}$, and $\beta-\mathrm{LG}$ variant $\mathrm{A}$ or $\mathrm{C}$. Thus, genetic selection of dairy cows for milk with good coagulation ability could improve cheese production, although milk coagulation is a complex trait influenced by many factors. Furthermore, 6 $\kappa-\mathrm{CN}$ isoforms varying in phosphorylation and glycosylation levels were separated and identified. Relative quantification showed that 95 to $96 \%$ of total $\kappa-\mathrm{CN}$ was phosphorylated, whereas 34 to $35 \%$ of identified $\kappa$-CN isoforms with up to 3 tetrasaccharides attached were glycosylated. Comparing individual samples, we found a very consistent $\kappa$-CN PTM pattern, independent of breed, genetic variant, or milk coagulation ability.

\section{ACKNOWLEDGMENTS}

The present work was supported by grants from Arla Foods amba (Viby J, Denmark), The Danish Cattle Federation (Skejby, Denmark), the Danish Strategic Research Council (Copenhagen, Denmark), Aarhus University (Tjele, Denmark), and an Australian Research Council Linkage project grant with Dairy Innovation Australia Ltd. (Sydney, Australia, grant UQ11128). The Danish sampling and analysis team at the Danish-Swedish Milk Genomics Initiative is gratefully acknowledged for excellent technical assistance.

\section{REFERENCES}

Auldist, M. J., S. J. Coats, B. J. Sutherland, J. F. Hardham, G. H. McDowell, and G. L. Rogers. 1996. Effect of somatic cell count and stage of lactation on the quality and storage life of ultra high temperature milk. J. Dairy Res. 63:377-386. 
Auldist, M. J., C. Mullins, B. O'Brien, B. T. O'Kennedy, and T. Guinee. 2002. Effect of cow breed on milk coagulation properties. Milchwissenschaft 57:140-143.

Caroli, A., P. Bolla, E. Budelli, G. Barbieri, and P. Leone. 2000. Effect of $\kappa$-casein $\mathrm{E}$ allele on clotting aptitude of Italian Friesian milk. Zoot. Nutr. Anim. 3:127-130.

Caroli, A. M., S. Chessa, and G. J. Erhardt. 2009. Invited review: Milk protein polymorphisms in cattle: effect on animal breeding and human nutrition. J. Dairy Sci. 92:5335-5352.

Coolbear, K. P., D. F. Elgar, and J. S. Ayers. 1996. Profiling of genetic variants of bovine $\kappa$-casein macropeptide by electrophoretic and chromatographic techniques. Int. Dairy J. 6:1055-1068.

Dalgleish, D. G. 1986. Analysis by fast protein liquid chromatography of variants of $\kappa$-casein and their relevance to micellar structure and renneting. J. Dairy Res. 53:43-51.

Danish Dairy Board. 2010. Dairy Statistics (Mejeristatistik 2009). Accessed Dec. 2011. http://www.lf.dk/Tal_og_Analyser/Aarstatistikker/Mejeristatistik/ /media/lf/Tal\%20og\%20analyser/ Aarsstatistikker/Mejeristatistik/2009/Mejeristatistik_2010_nettet.ashxdalgleish dg.

Di Stasio, L., and P. Mariani. 2000. The role of protein polymorphism in the genetic improvement of milk production. Zoot. Nutr. Anim. 26:69-90

Ekstrand, B., M. Larsson-Raznikiewicz, E. Brannang, and C. Swensson. 1981. Size distribution of casein micelles related to coagulation properties - A comparison between different breeds of cattle. Swed. J. Agric. Res. 11:57-61.

Feagan, J. T., L. F. Bailey, A. F. Hehir, D. M. McLean, and N. J. S. Ellis. 1972. Coagulation of milk proteins. I. Effect of genetic variants of milk proteins on rennet coagulation and heat stability of normal milk. Aust. J. Dairy Technol. 27:129-134.

Fiat, A. M., J. Chevan, P. Jollès, P. De Waard, J. F. Vliegenthart, F. Piller, and J. P. Cartron. 1988. Structural variability of the neutral carbohydrate moiety of cow colostrum $\kappa$-casein as a function of time after parturition. Identification of a tetrasaccharide with blood group I specificity. Eur. J. Biochem. 173:253-259.

Fox, P. F., and P. L. H. McSweeney. 1998. Dairy Chemistry and Biochemistry. Blackie Academic and Professional, London, UK.

Frederiksen, P. D., K. K. Andersen, M. Hammersh $\varnothing$ j, H. D. Poulsen, J. Sørensen, M. Bakman, K. B. Qvist, and L. B. Larsen. 2011a. Composition and effect of blending on noncoagulating, poorly coagulating, and well-coagulating bovine milk from individual Danish Holstein cows. J. Dairy Sci. 94:4787-4799.

Frederiksen, P. D., M. Hammershøj, M. Bakman, P. N. Andersen, J. B. Andersen, K. B. Qvist, and L. B. Larsen. 2011b. Variations in coagulation properties of cheese milk from three Danish dairy breeds as determined by a new free oscillation rheometry-based method. Dairy Sci. Technol. 91:309-321.

Green, M. L., and S. V. Morant. 1981. Mechanism of aggregation of casein micelles in rennet-treated milk. J. Dairy Res. 48:57-63.

Hallén, E., T. Allmere, J. Naslund, A. Andren, and A. Lunden. 2007. Effect of genetic polymorphism of milk proteins on rheology of chymosin-induced milk gels. Int. Dairy J. 17:791-799.

Hallén. E. A. Wedholm, A. Andrén. and A. Lundén. 2008. Effect of $\beta$-casein, $\kappa$-casein and $\beta$-lactoglobulin genotypes on concentration of milk protein variants. J. Anim. Breed. Genet. 125:119-129.

Heck, J. M., A. Schennink, H. J. van Valenberg, H. Bovenhuis, M. H Visker, J. A. van Arendonk, and A. C. van Hooijdonk. 2009. Effects of milk protein variants on the protein composition of bovine milk. J. Dairy Sci. 92:1192-1202.

Holland, J. W. 2009. Post-translational modifications of caseins. Pages 107-132 in Milk Proteins: From Expression to Food. A. Thompson, M. Boland, and H. Singh, ed. Academic Press, San Diego, CA.

Holland, J. W., H. C. Deeth, and P. F. Alewood. 2004. Proteomic analysis of $\kappa$-casein micro-heterogeneity. Proteomics 4:743-752.

Holland, J. W., H. C. Deeth, and P. F. Alewood. 2005. Analysis of $O$-glycosylation site occupancy in bovine k-casein glycoforms separated by two-dimensional gel electrophoresis. Proteomics 5:9901002

Holland, J. W., H. C. Deeth, and P. F. Alewood. 2006. Resolution and characterization of multiple isoforms of bovine kappa-casein by
2-DE following a reversible cysteine-tagging enrichment strategy. Proteomics 6:3087-3095.

Ikonen, T., K. Ahlfors, R. Kempe, M. Ojala, and O. Ruottinen. 1999. Genetic parameters for the milk coagulation properties and prevalence of noncoagulating milk in Finnish dairy cows. J. Dairy Sci. $82: 205-214$

Ikonen, T., S. Morri, A. M. Tyriseva, O. Ruottinen, and M. Ojala. 2004. Genetic and phenotypic correlations between milk coagulation properties, milk production traits, somatic cell count, casein content and $\mathrm{pH}$ of milk. J. Dairy Sci. 87:458-467.

Ikonen, T., M. Ojala, and E. L. Syvaoja. 1997. Effects of composite casein and $\beta$-lactoglobulin genotypes on renneting properties and composition of bovine milk by assuming an animal model. Agric. Food Sci. Finland 6:283-294.

Jann, O., G. Ceriotti, A. Caroli, and E. Erhardt. 2002. A new variant in exon VII of bovine $\beta$-casein gene (CSN2) and its distribution among European cattle breeds. J. Anim. Breed. Genet. 119:65-68.

Joudu, I., M. Henno, S. Varv, T. Kaart, O. Kart, and K. Kalamees. 2007. Milk protein genotypes and milk coagulation properties of Estonian native cattle. Agric. Food Sci. 16:222-231.

Lien, S., J. Kantanen, I. Olsaker, L.-E. Holm, E. Eythorsdottir, K. Sandberg, B. Dalsgard, and S. Adalsteinsson. 1999. Comparison of milk protein allele frequencies in Nordic cattle breeds. Anim. Genet. 30:85-91.

Lundén, A., M. Nilsson, and L. Janson. 1997. Marked effect of $\beta$-lactoglobulin polymorphism on the ratio of casein to total protein in milk. J. Dairy Sci. 80:2996-3005.

Marziali, A. S., and K. F. Ng-Kwai-Hang. 1986. Effects of milk composition and genetic polymorphism on cheese composition. J. Dairy Sci. 69:2533-2542

Mollé, D., and J. Léonil. 1995. Heterogeneity of the bovine $\kappa$-casein caseinomacro-peptide, resolved by liquid chromatography on-line with electrospray ionization mass spectrometry. J. Chromatogr. A $708: 223-230$.

O'Brien, B., R. Mehra, J. F. Connolly, and D. Harrington. 1999. Seasonal variation in the composition of Irish manufacturing and retail milks. 1. Chemical composition and renneting properties. Ir. J. Agric. Food Res. 38:53-64.

O'Connell, J. E., and P. F. Fox. 2000. The two-stage coagulation of milk proteins in the minimum of the heat coagulation time-pH profile of milk: Effect of casein micelle size. J. Dairy Sci. 83:378-386.

Oloffs, K., H. Schulte-Coerne, K. Pabst, and H. O. Gravert. 1992. Die Bedeutung der Proteinvarianten für genetische Unterschiede in der Käsereitauglichkeit der Milch. Zuchtungskunde 64:20-26.

Pisano, A., N. H. Packer, J. W. Redmond, K. L. Williams, and A. A. Gooley. 1994. Characterization of $O$-linked glycosylation motifs in the glycopeptide domain of bovine $\kappa$-casein. Glycobiology 4:837-844.

Robitaille, G., K. F. Ng-Kwai-Hang, and H. G. Monardes. 1991a. Variation in the $N$-acetyl neuraminic acid content of bovine $\kappa$-casein J. Dairy Res. 58:107-114.

Robitaille, G., K. F. Ng-Kwai-Hang, and H. G. Monardes. 1991b. Association of $\kappa$-casein glycosylation with milk production and composition in Holsteins. J. Dairy Sci. 74:3314-3317.

Saito, T., and T. Itoh. 1992. Variations and distributions of o-glycosidically linked sugar chains in bovine $\kappa$-casein. J. Dairy Sci. 75:1768-1774.

Sandra, S., M. Alexander, and D. G. Dalgleish. 2007. The rennet coagulation mechanism of skim milk as observed by transmission diffusing wave spectroscopy. J. Colloid Interface Sci. 308:364-373.

Schaar, J., B. Hansson, and H. Pettersson. 1985. Effects of genetic variants of $\kappa$-casein and $\beta$-lactoglobulin on cheese-making. J. Dairy Res. 52:429-437.

Summer, A., S. Visser, C. J. Slangen, L. Di Stasio, and P. Mariani. 1996. Occurrence of the $\beta$-casein $F$ variant in the milk of Italian Friesian cows. Ann. Fac. Med. Vet. Parma 16:96-102.

Tyriseva, A. M., K. Elo, A. Kuusipuro, V. Vilva, I. Janonen, H. Karjalainen, T. Ikonen, and M. Ojala. 2008. Chromosomal regions underlying noncoagulation of milk in Finnish Ayrshire cows. Genetics 180:1211-1220. 
Tyriseva, A. M., T. Vahlsten, O. Routtinen, and M. Ojala. 2004. Noncoagulation of milk in Finnish Ayrshire and Holstein-Friesian cows and effect of herds on milk coagulation ability. J. Dairy Sci. 87:3958-3966.

van Halbeek, H., L. Dorland, J. F. Vliegenthart, A. M. Fiat, and P. Jolles. 1980. A $360-\mathrm{MHz} 1 \mathrm{H}-\mathrm{NMR}$ study of three oligosaccharides isolated from cow kappa-casein. Biochim. Biophys. Acta 623:295-300.

Verdier-Metz, I., J. B. Coulon, P. Pradel, C. Viallon, and J. L. Berdague. 1998. Effect of forage conservation (hay or silage) and cow breed on the coagulation properties of milks and on the characteristics of ripened cheeses. J. Dairy Res. 65:9-21.

Visker, M. H. P. W., B. W. Dibbits, S. M. Kinders, H. J. F. van Valenberg, J. A. M. van Arendonk, and H. Bovenhuis. 2011. Association of bovine $\beta$-casein protein variant I with milk production and milk protein composition. Anim. Genet. 42:212-218.

Vreeman, H. J., S. Visser, C. J. Slangen, and J. A. Van Riel. 1986. Characterization of bovine kappa-casein fractions and the kinetics of chymosin-induced macropeptide release from carbohydrate-free and carbohydrate-containing fractions determined by high-performance gel-permeation chromatography. Biochem. J. 240:87-97.

Wedholm, A., L. B. Larsen, H. Lindmark-Mansson, A. H. Karlsson, and A. Andren. 2006. Effect of protein composition on the cheesemaking properties of milk from individual dairy cows. J. Dairy Sci. 89:3296-3305. 